RAD Conference Proceedings, vol. 4, pp. 32-38, 2020

ISSN 2466-4626 (online) | DOI: 10.21175/RadProc.2020.07

www.rad-proceedings.org

\title{
PSYCHOLOGICAL ASPECTS OF IONIZING RADIATION EXPOSURE
}

\author{
Snežana Živkovićc ${ }^{*}$ Milan Veljković
}

University of Niš, Faculty of Occupational Safety, Niš, Serbia

\begin{abstract}
All life on our planet is surrounded by radiation. Human life takes place with a certain level of radiation. The term psychologically is used primarily to explain the emotional reactions of the public, on issues in relation to which one should have a rational relationship because every story about radiation causes fear and rejection in an "unprofessional" and "conscientious" citizen. Over the past seventy years, a general opinion has been created through the mass media about the deadly effects of radiation. Apart from the real fear, which arises from the feeling of ecological endangerment, and which is based on the objective dangers of modern technologies, irrational fear is inevitably born. It is a generalization of all human subjective sufferings within the framework of "overestimated" reality. The feeling of fear that we are exposed to radiation can have far greater consequences than the actual harmful effects of physical radiation. The aim of this paper is to identify the psychological effects that radiation can cause in humans and how to overcome fear and stressful situations caused by radiation and the effect of psychosocial factors on human behavior, but also elements for prognosis and prediction for their behavior in similar situations. There is a justified concern when the risk of radiation appears, but the reality is far from the amount of panic that is spreading in the public and the media when it comes to these phenomena. We can conclude that people are generally afraid of radiation because their beliefs are dominated by misconceptions, delusions, or opinions that are the product of errors of judgment or are based on false premises.
\end{abstract}

Keywords: Emotional reactions, fear, psychology, radiation, stress

\section{INTRODUCTION}

All life on our planet is surrounded by radiation. Asphalt radiates on warm days, the sun radiates, radiators radiate in our homes. Every time passengers board a plane they are exposed to radiation. As the plane reaches altitude, these same passengers receive another minimal dose from the cosmic rays in the atmosphere. There is also natural radiation in the stone we use to build our buildings and houses as well as on the ground that surrounds them. There is also radiation from medical technologies such as X-rays and cut scans, and even potassium, which is found in some types of fruits and vegetables. Some parts of the total amount of potassium that we take into the body are radioactive and that radiation from these types of potassium makes up some of the basic types of radiation to which we are constantly exposed. Human life takes place with a certain level of radiation [1]. Whatever the impact, it has always been there, and the question is are we at any increased risk of what might be released from the reactor? In almost every situation, no matter how much the risk is increased, it is exceedingly small [2]. Paul Slovic conceptualises risk perception along two dimensions: dread risk and unknown risk. "Dread risk," is defined at its high end by perceived lack of control, dread, catastrophic potential, fatal consequences, and the inequitable distribution of risks and benefits. Nuclear weapons and nuclear power score highest on the characteristics that make up this factor. "Unknown risk," is defined at its high end by hazards judged to be unobservable, unknown, new, and delayed in their manifestation of harm [3].

The term psychologically is used primarily to explain the emotional reactions of the public, on issues in relation to which one should have a rational relationship, because almost every story about radiation causes fear and rejection in an "unprofessional" and "conscientious" citizen. The feeling of fear that we are exposed to radiation can have far greater consequences than the actual harmful effects of physical radiation. Over the past seventy years, a general opinion has been created through the mass media about the deadly effects of radiation [4].

That is why most of people are afraid of radiation, and even the very thought of radiation foretells unpleasant associations and feelings. People have been listening to and absorbing information for so long that radiation is deadly that these words have become the basis for defining and understanding radiation exposure. Radiation may cause death only as a result of exposure to extreme radiation conditions. Few people know radiation is used for medical purposes.

Natural radiation is all around us and is inevitable, so the risk (hypothetically or epidemiologically) of natural radiation is an integral part of life [5]. This unavoidable exposure to natural radiation also represents the natural lower limit for radiation protection in terms of dose and risk reduction. Reducing the contribution of radiation exposure below natural limits is not justified and reasonable, represents an unjustified waste of resources and

* snezana.zivkovic@znrfak.ni.ac.rs 
increases the already unjustified / irrational fear of radiation in the general public [5].

\section{IONIZING AND NON-IONIZING RADIATION}

Non-ionizing radiation originates from low frequencies, including those corresponding to the ultraviolet spectrum. This includes the radio frequency range and the visible part of the spectrum. The highest radio frequencies correspond to microwave radiation at millimeter wavelengths (corresponding to the frequency range from 30 to $300 \mathrm{GHz}$ ) and those, if high powers are used, can produce a thermal effect as a harmful effect. Therefore, it is not recommended to hold the mobile phone in ways when it is necessary to look at the screen. Simply put, when the device that produces on your ears for too long. After all, smartphones are moving further and further away from the head, because new applications radio frequency radiation stops working (switches off), the radiation also stops. Non-ionizing radiation does not change the substance that is exposed to them [6].

Unlike non-ionizing radiation, ionizing radiation has enough energy to break the bonds inside the atom and release electrons, which ionizes the matter they attack. The effect of this radiation involves destruction and alteration of DNA, and is therefore avoided, except for the purpose of scanning. Ionizing radiation is the phenomenon of energy transfer in the form of photons (quantum of electromagnetic radiation) or particles which has enough energy to ionize this substance during the interaction with the chemical substance. Ionizing radiation is a consequence of a change in the state of matter in the microcosm. These are changes in energy or in the composition of an atom or atomic nucleus, emitting photons or other particles. In interaction with matter, there is a change in energy and a change in the structure of the irradiated substance. Such consequences can be beneficial, but also very harmful. Ionizing radiation is a phenomenon for which the human senses are not developed, unlike many other phenomena in nature. The direct effects of ionizing radiation on the living world are mostly delayed and it is difficult to connect them with the cause. It can also be exposed to a lethal dose of ionizing radiation, without feeling anything during the radiation itself. The effects of radiation, without sensory connection with the cause, are noticed only after some time, from a few hours to a few days or even years, which depends on the type and properties of that radiation. Therefore, human fear is understandable, and knowledge of the basic properties of ionizing radiation, the interaction of radiation with matter, and especially the effect of radiation on living beings, is extremely important in a professional and psychological sense. Ionizing radiation can consist of a beam of high-energy particles (protons, alpha particles, or beta particles) or high-frequency electromagnetic radiation (gamma radiation, X-rays, ultraviolet radiation). Ionizing radiation can have a detrimental effect on the molecules of substances, and especially on biological tissues. However, the human body can regenerate to a lesser extent even with such radiation. If the limit threshold of radiation is exceeded, then cell damage occurs and the consequence of ionizing radiation can be loss of life, i.e. malignant disease. A large part of the ultraviolet spectrum produces ionizing radiation. Therefore, long exposures to the sun, i.e. the use of a solarium, are not recommended [7].

\section{FEAR OF RADIATION}

\subsection{Fear of radiation and how to overcome it}

Despite the ubiquity of ionizing radiation in the life of modern man, he does not have enough information about it. That knowledge is very specialized, and as such, in fact inaccessible. The media deal with this issue in their own way of placing and processing information, which is most often disturbing for the public. Apart from the real fear, which arises from the feeling of ecological endangerment, and which is based on the objective dangers of modern technologies, irrational fear is inevitably born. It is a generalization of all human subjective sufferings within the framework of "overestimated" reality. Radiophobia is a term that explains this type of fear which is in fact a type of almost hysterical phenomenon. Given that the factors that affect the impairment of mental health are numerous and act together, it is impossible in everyday life to assess and quantify, nor fully qualify the impact of radiation as a stressor on mental health [8].

Fear as an emotion caused by impending danger is a natural reaction of a man who feels the need to hide or save himself by fleeing [9]. In the generally accepted psychological perception, fear is an emotion that arises in situations of endangering the biological or social existence of an individual and is directed at the source of real or imaginary danger. Fear, unlike pain and other forms of suffering, manifests itself in anticipation of danger, depending on whose characteristics, intensity, and specificity of experiencing fear varies in a wide range of shades (fear, apprehension, horror, horror). Fear allows attention to be directed to the source of danger and encourages the search for a way out of it. In cases when it reaches the strength of affect (panic fear, fear), fear can impose specific stereotypes of behavior on a person and subdue them (escape, stiffness, protective aggression) [10].

Fear of personal physical injury and one's own death are the original and most meaningful causes that cause fear and are causally related to the instinct of self-preservation that characterizes all living beings. Namely, the less protected a person is, the more frequent this instinct is with him [11]. Fear has a strong influence on perceptual-cognitive processes and behavior in general. Namely, when feeling fear, attention often narrows sharply and focuses on the object or situation that predicts danger. Figuratively, in fear a person does not belong to himself and is driven by the desire to remove the threat and avoid danger, where weak fear is experienced as anxiety. Anxiety is a hovering, vague fear. The feeling of anguish, agitation and tension, which differs from fear in its complexity, but also in its vagueness, indeterminacy, since it is not tied to a certain object. This unpleasant feeling is dominated by the anticipation of some great but indefinite misfortune, the helpless expectation that 
something terrible will inevitably happen, some great evil [12].With increasing fear, a person feels increasing insecurity in himself and his security, where intense fear is experienced as a feeling of complete insecurity and insecurity regarding his security. There is a feeling of threat to one's physical and (or) mental integrity, and in certain cases, threat to one's life [11].

The first rule that helps to overcome fear is the ability to assess the reality and magnitude of the threat and the possibility of obtaining help. It is important not to give in to fear, and especially to the strongest "delayed" fear. Since in the first moments fear is not characterized by a strong intensity, it is not able to completely overwhelm a person, while the inertia of the previous state helps to oppose fear.

Usually, after the disappearance of a specific threat, it becomes difficult. In order to deal with this fear, it is necessary to learn how to simply "switch" in the sense that it does not "get stuck" in past situations and that they do not "rewind" for too long, returning to the same events. Simply put, there is no need to be afraid. In particular, one should not be afraid of something whose probability is small. However, it is evident that people often do not know how to be afraid of what they should be afraid of [13].

\subsection{How the fear of radiation arose}

People are afraid of radiation, because they have mostly heard about radiation in the media through shocking and bad news. Although radiation is used daily in medical diagnostics and cancer treatment, such news is very rarely reported. Continuous reporting of radiation as bad has resulted in strong ingrained fears of radiation. We can conclude that people are generally afraid of radiation because their beliefs are dominated by misconceptions, delusions, or opinions that are the product of errors of judgment or are based on false premises.

A person does not even have to be exposed to radiation for fear to occur, it is enough for the person to think that there is a possibility or for the person to think that he is exposed to radiation. A person who is afraid of radiation will try to avoid a situation that may be related to radiation, although most of these people accept the benefits of using radiation for medical purposes and are not afraid of radon radiation in their homes as a natural part of the environment in which they live. Any radiation that is not medical or natural is often considered automatically bad. The term "lethal radiation" is often mentioned in the media for many years, so most people believe that these two words automatically go together. It can produce a logical error or error in reasoning where a direct connection between cause (radiation) and consequence (health hazards) is assumed [14].

\section{NUCLEAR DISASTERS}

The problem gained its full significance with the outbreak of nuclear disasters. The aim of psychology is to determine the effect of psychosocial factors on the behavior of people in specific crisis situations, but also elements for forecasting and predicting their behavior in similar situations [15]. Irradiation because of nuclear accidents, regardless of size, is not an ordinary catastrophe because radiation has very specific characteristics. The nuclear accident situation has its own dynamics, considering the beginning, duration and consequences, and the radiation has specific characteristics in relation to other types of catastrophes.

The fact that radiation cannot be directly perceived or felt by the senses and that its destructive power can be felt tens of thousands of kilometers outside the crash site, affect the appearance and dominance of strong emotions in mass behavior. Emotional states experienced by people in the form of fear, axiosis, anger, hatred and similar effects lead to a narrowing of the consciousness of the individual in the mass, nor do they lose their identity and ability to solve the critical current situation with their intellectual and other psychic functions. Such reactions to stress are characteristic of the initial period of a catastrophe. The time required for recovery from stress is the main characteristic of people's behavior in an accidental situation, and this process takes place through adequate and inadequate behavior. It can be individual and mass. Adequate behavior is what seems most appropriate for overcoming a catastrophe in the given circumstances. Its important element is the possession of knowledge and training appropriate to the nature of the disaster. The problem with nuclear accidents is that, in addition to the experts from that area, ordinary citizens must also have specific professional knowledge in a certain way. Unlike other crisis situations, where adequate behavior is common sense, that is, that which is guided by natural psychosocial human traits, in nuclear disasters, adequate behavior is primarily based on adequate information. However, uncritical information, misperception, and assessment of the situation with the general state of confusion are intensified by the dependence on the source of information that informs about the accident. It is characteristic of nuclear catastrophes that a person is forced to rely only and exclusively on information from competent experts who do not fully understand and whom I always do not trust and cannot verify this information [15].

Inadequate reactions do not overcome the crisis. Inadequate reactions are mostly psychopathological, but they do not always have to be. Mass, inadequate reactions include panic, whose fear is based on propaganda activity or rumors. The problems we talked about when informing the public in this context come to the maximum. Overall, such massive, inadequate reactions do not last long, in nuclear accidents they last a bit longer, given the fact that the end of accidents does not mean the end of exposure to stressors, which the population is aware of.

Due to the prolonged duration of the accident and depending on the personality structure, induced neurotic reactions of various forms (hysterical, anxiety, depressive, dissociative) can be expected, as well as psychotic individual reactions [16].

In fact, fear of the effects of radiation can only be resolved by considering the following issues: 
What is a radiation source? How big is the radiation source? What type of radiation does the source emit? We also need to know how much radiation does that source emit? Where the radiation source is located and how far is the source from people?

The answers to these questions can assess the possible consequences based on the observation and monitoring of people who have been exposed to radiation and in whom we can monitor the impact of radiation on them. The first research was done in Japan. The subjects were atomic bomb survivors. After observing 80,000 survivors over 70 years and comparing a uniform sample of people who were not exposed to atomic bomb radiation. The study concluded that approximately 400 people died because of radiation exposure. This is only about half the percentage of survivors, which tells us that people who survive an explosion, heat, and immediate exposure to radiation have truly little chance of dying from radiation later [17].

Radiation is deadly only in extreme conditions. The analogy with describing radiation as lethal is like taking an extreme amount of caffeine (100 tablets could be lethal) and then describing the use of one headache pill as a dose of lethal caffeine.

Shortly after the nuclear disaster in Japan, many pharmacies in the United States reported receiving calls from Americans looking for potassium iodide pills that they believed could protect them from the radioactive iodine found in the gases emitted by nuclear power plants.

Although in any case there was no danger, how many dangers could the pill itself cause [18]. People tend to believe the media and what they see and hear on television [19].

Many untruths and myths about radiation have been spread through the media for many years. This inaccurate information has been accepted as fact because it has been reported for decades. It is probable that the journalists themselves were not aware that they were not reporting objectively but were reporting based on what they had always heard. The results of such journalistic reporting have led to radiation fears appearing to be commensurate with the risk of radiation. Because the media only reports "bad news" about radiation, everyone has learned to be afraid and avoid radiation at all costs. People are most afraid of what they know the least [20], and most people do not know much about radiation, except for the information they receive through the media.

\section{MisCONCEPTIONS THAT MOST PEOPLE BELIEVE}

\subsection{Does radiation shorten life?}

Persistent insistence on the linear radiation model (LNT) as the only inviolable model has led to a series of errors. The LNT model implies that there is no safe dose of radiation and every, literally every, dose can cause cancer in the final analysis.

LNT also introduced the term collective dose. It is the sum of all radiation doses to the entire population and based on the large numbers thus obtained, it assumes the number of deaths caused by radiation. If on average each person receives $5 \mathrm{mSv}$ per year, then 1.8 million people die from cancer every year [21]. The problem is that ordinary metabolism damages cells much more and more often, and there is also an excellent protection mechanism.

The WHO continues to stubbornly calculate everything based on the LNT. Other organizations show that they are slowly realizing that this model does not apply to small doses. Thus, back in 2007, the ICRP recommended that LNT could not be used as a tool in epidemiological studies [22].

\subsection{There is no safe level of radiation}

It is a belief in radiation for which even radiation experts do not have a single agreement. The risk of ionizing radiation to health varies with dose and radiation type. Unfortunately, there are many additional factors that people generally do not understand the impact of radiation. Sources of natural radiation are estimated at an average of 310 mrem (millirem) per year (mrem, a unit of radiation energy deposited in the body). In some parts of the world, normal background radiation can give annual doses of 1,000 mrem to 25,000 mrem, without any noticeable effects.

\subsection{Radiation will kill you}

Contrary to the guesses of the media after the atomic bomb in Japan, which reported that living conditions would change and that genetic damage in the population would occur in the next 1000 years, such damage did not occur.

Atomic bomb survivors may even live longer than normal. Contrary to popular belief, radiation is not the most devastating result of a nuclear bomb. Based on events in Japan, if you survive the heat and explosion, the chances of dying from radiation are relatively small [17].

\subsection{Number of deaths in Chernobyl}

If you enter a search on the number of Chernobyl deaths in a Google search engine, you will get hundreds of websites reporting 50,000 to 500,000 deaths in the search results. It is true that there are approximately 50 people, including the managers and workers of the plant where the disaster occurred. About twenty deaths were caused by childhood thyroid cancer [23]. So where do the hundreds of thousands of deaths come from? The answer is based on the use of theoretical calculations, but the websites do not say so. Radiation safety experts know that such theoretical calculations have no basis [24]. From the way the public and the media perceive the risks of radiation, it can be concluded that radon exposure and exposure to a CT scanner are not considered hazardous to health. People seem to have a concept of good radiation and bad radiation. If the radiation occurs in nature (like radon) or if your doctor prescribes it (like CT), it is obvious that these types of radiation are fine. At least the public does not seem very worried about these radiation sources. The question that arises here is: do our bodies 
react differently to the radiation source? Of course, our bodies do not differentiate that $[25,26]$.

\subsection{You will shine in the dark if you are irradiated}

Shining in the dark as a reaction to radiation is one of the most widespread ideas. This idea probably dates to the early years of the twentieth century, when fluorescent colors were used for night lighting of clocks, and instrument panels [27].

\subsection{Granite slabs are harmful to health}

The media warned that household owners should be careful of radiating granite slabs. These claims are partly true because granite can contain small amounts of radium and uranium. Also, these radioactive elements, as natural elements, are part of all materials coming from the earth [28, 29].

\subsection{Why are radiation misconceptions so popular?}

That is why misconceptions help to be explained 'inexplicably' in terms that are simplistic, easy to understand and which seem simple, direct, and seem meaningful and logical so that the general public can easily accept them. Journalists mention them because they refer to what was said and accepted earlier. Persuasiveness and frequent repetition can be further enhanced by pictures, movies, or anecdotes that. The belief in "lethal radiation" helps to establish a direct link between the cause (radiation) and the health effect (cancer).

It is much easier to trust people who say what we agree with. Also, it is easier to believe rumors, gossip that are in line with our attitudes and beliefs [30]. It is much harder to believe those who say something different, when they say something that contradicts our attitudes and beliefs, especially when spoken in an unknown language of science. Radiation protection experts have tried to combat radiation misconceptions by disclosing accurate information [31]. They were surprised that people did not understand or did not want to hear what they were saying. Most people are afraid of radiation and in a state of fear as a basic instinct of feelings they take control and not rational thinking.

\section{THE ROLE OF THE MEDIA}

People from the media worked selflessly, there were good moments but the basic tone was influenced by indoctrination with fear of radiation. This is understandable because the situation of a person in relation to that fear is psychologically difficult: he does not understand himself and cannot even check the information, the world is buzzing about it, and experts do not agree. Key people from the media, however, are responsible for not using the strong interest of the public and the power of the media, especially television, to come to the truth in a public confrontation of experts. Some journalists reported very biasedly and spread half-truths and intimidated the already manipulated public opinion. The media should be responsible for professional information and consult with experts before publishing information. Both should present the professional truth in such a way that the layman and the unprofessional public understand it correctly, because the truth misunderstood in public is nothing but deception. The truth about the risk and consequences of radiation is not sensational, it is not popular, so it is not desirable in the public media.

Risk perception research paints a different picture, demonstrating that people's deep anxieties are linked to the reality of extensive unfavorable media coverage and to a strong association between nuclear power and the proliferation and use of nuclear weapons. Attempts to "educate" or reassure the public and bring their perceptions in line with those of industry experts appear unlikely to succeed because the low probability of serious reactor accidents makes empirical demonstrations of safety difficult to achieve. Because nuclear risks are perceived as unknown and potentially catastrophic, even small accidents will be highly publicized and may produce large ripple effects [3].

Due to the constant use and repetition of the word "deadly radiation through the media," it can be assumed that the presence of radiation will lead to terrible consequences, probably cancer and death. In this way, through emotional conditioning, the very thought of radiation in our head creates images of catastrophic consequences that are a consequence of radiation, so it is not at all surprising why many people are afraid of radiation. The great concern is a consequence of ingrained fear [32]. There is a concern when the risk of radiation appears, but the reality is far from the amount of panic that is spreading in the public and the media when it comes to these phenomena. We can conclude that people are generally afraid of radiation because their beliefs are dominated by misconceptions, delusions or opinions that are the product of errors of judgment or are based on false premises.

\section{CONCLUSION}

Continuous reporting of radiation as bad has resulted in strong ingrained fears of radiation. We can conclude that people are generally afraid of radiation because their beliefs are dominated misconceptions, delusions or opinions that are the product of errors of judgment or are based on false premises. Fear as a negative feeling that a person experiences when he sees or expects danger is a primary emotion, an innate, genetically programmed reaction to a threatening or painful stimulus. Bearing in mind that fear is an emotion that arises in situations of endangering the biological or social existence of an individual and is directed at the source of danger or imaginary danger and that it represents a certain type of protective reaction of a person. There is a justified concern when the risk of radiation appears, but the reality is far from the amount of panic that is spreading in the public and the media when it comes to these phenomena. The effects of radiation are "relatively studied and very clear and in complete discrepancy with the usual media and public perception." Lack of concrete data and classification of information by anarchy lead to 
spontaneous and irrational behavior of many people and lowering the criticality threshold of rumors that appear. The problem, however, is that different uses of radiation are treated the same.

Radiation is used in medicine and is also used for the process of food sterilization through irradiation there is a tendency in the media to put it all in the same basket with bad radiation. The main reason why people are afraid of radiation is unpreparedness and ignorance. Most people are poorly prepared to act rationally in case of radiological danger.

Acknowledgements: This paper is the result of research funded by the Ministry of Education, Science and Technological Development of the Republic of Serbia.

\section{REFERENCES}

1. National Research Council, Health Risks from Exposure to Low Levels of Ionizing Radiation: BEIR VII Phase 2. Washington, DC: The National Academies Press, 2006.

http://doi.org/10.17226/11340

2. National Research Council (US) Committee on the Biological Effects of Ionizing Radiation (BEIR V), Health Effects of Exposure to Low Levels of Ionizing Radiation: Beir V, Washington (DC): National Academies Press (US), 1990, pp. 22-45.

Retrieved from:

http://www.ncbi.nlm.nih.gov/books/NBK218704/ http://doi.org/10.17226/1224

3. P. Slovic, Perception of risk. Science, vol. 236, pp. 280-285, Apr. 1987. http://doi.org/10.1126/science.3563507

4. Y. Kim, "The radiation problem and its solution from a health communication perspective," J. Korean Med. Sci., vol. 31(Suppl 1), pp. S88-S98, Jan. 2016. http://doi.org/10.3346/jkms.2016.31.S1.S88

5. R. Michel, B. Lorenz, H. Völkle, Radiation protection today - success, problems, recommendation for the future. Statement paper of the "Club of the Philosophers" of the German-Swiss Association for Radiation Protection, 2018.

Retrieved from: https://fsev.org/fileadmin/user upload/og Themen/Philosoph en/Future of Radiation Protection 20180921.pdf

6. B. Popović, "Uticaj $\gamma$-zračenja na antioksidativni sistem odabranih genotipova soje i pojava oksidativnog stresa," Doktorska disertacija, Univerzitet u Novom Sadu, Prirodno-matematički fakultet, Novi Sad, Srbija, 2006.

(B. Popović, "Influence of $\gamma$-radiation on antioxidant system of selected genotypes of soybean and oxidative stress appearance," Ph.D. thesis, University of Novi Sad, Faculty of Science, Novi Sad, Serbia, 2006) Retrieved from:

http://nardus.mpn.gov.rs/handle/123456789/5925

7. A. Perić, „Spektralne karakteristike veštačkih izvora UV zračenja-solarijumi," diplomski rad, Univerzitet u Novom Sadu, Prirodno-matematički fakultet, Novi Sad, Srbija, 2007.

(A. Perić, "Spectral characteristics of artificial sources of UV radiation - solariums," Diploma work, University of Novi Sad, Faculty of Science, Novi Sad, Serbia, 2006) Retrieved from: https://www.df.uns.ac.rs/publikacije/diplomskiradovi/
8. B.M. Drottz-Sjöberg, L. Persson, Public reaction to radiation: fear, anxiety, or phobia?. Health Physics, vol. 64, no. 3, pp. 223-231, Mar. 1993. http://doi.org/10.1097/00004032-199303000-00001

9. Н. Коупленд, Психология и солдат / Пер. с англ., Москва, Россия: Воениздат, 1991.

(N. Copeland, "Psychology and the Soldier," Translation of English, Moscow, Russia: Voenizdat, 1991.)

10. К.Э. Изард, Эмоции человека, Психологический этюд, Москва, Россия: МГУ, 1980.

(C.E. Izard, The psychology of emotions. Moscow, Russia: MGU, 1991.)

11. C.E. Izard, The psychology of emotions. New York, USA: Springer Science \& Business Media, 1991.

12. Ž. Trebješanin, Rečnik psihologije. Beograd: Stubovi kulture. 2000.

13. Т. Ш. Нагимов, Э.С. Русаев, Г.Г. Нигаматуллина, Психология человека в местах массового пребывания населения. Паника и её предотвращение. Уфа: ГУ МЧС России по Республике Башкортостан, 2005.

(T. Sh. Nagimov, E. S. Rusaev, G.G. Nigamatullina, Human psychology in places of mass presence of the population. Panic and its prevention. Ufa: GU EMERCOM of Russia in the Republic of Bashkortostan, 2005.)

14. D. Ropeik, "Fear vs. radiation: the mismatch." The New York Times, Oct. 21, 2013.

Retrieved from:

https://www.nytimes.com/2013/10/22/opinion/fearvs-radiation-the-mismatch.html

15. M. Zvonarević, Đ. Matošić, I. Mišković, P. Sekulić, Čovjek u zaštiti i spašavanju, Zagreb, Jugoslavija: Školska knjiga, 1986.

(M. Zvonarević, Đ. Matošić, I. Mišković, P. Sekulić, Man in Protection and Rescue, Zagreb, Yugoslavia: Školska knjiga, 1986.)

16. J.R. Croft, P. Zuniga-Bello, A. Kenneke, "The radiological accident in San Salvador.” In Recovery operations in the event of a nuclear accident or radiological emergency: Proceedings Series, Vienna, Austria: IAEA, 1990.

17. B.R. Jordan, "The Hiroshima/Nagasaki survivor studies: discrepancies between results and general perception," Genetics, vol. 203, no. 4, pp. 1505-1512, Aug. 2016. http://doi.org/10.1534/genetics.116.191759

18. M. Durigon, T. Kosatsky, "Calls managed by the BC Drug and Poison Information Centre following the 2011 nuclear reactor incident at Fukushima, Japan." Canad. Pharm. J., vol. 145, no. 6, pp. 256-258, Nov. 2012. http://doi.org/10.3821/145.6.cpj256

19. Y. Tsfati, J. Cohen, J. Perceptions of media and media effects: The third person effect, trust in media and hostile media perceptions. In The international encyclopedia of media studies: media effects/media psychology, 1st ed.., A.N. Valdivia, E. Scharrer. Eds., Oxford, UK: Willey-Blackwell, 2013, ch. 5, pp. 1-19.

20. C.C. Chow, R.K. Sarin, Known, unknown, and unknowable uncertainties, Theory Decision, vol. 52, no. 2, pp. 127-138, Mar. 2002. http://doi.org/10.1023/A:1015544715608

21. C.J. Martin, "The LNT model provides the best approach for practical implementation of radiation protection," Br. J. Radiol., vol. 78, no. 925, pp. 14-16, Jan. 2014. http://doi.org/10.1259/bjr/31745335

22. C. Streffer, "The ICRP 2007 recommendations," Radiat. Prot. Dosimetry., vol. 127, no. 1-4, pp. 1-7, Oct. 2007. http://doi.org/10.1093/rpd/ncm246

23. R. Bertell, "First Assessment of the actual death toll attributable to the Chernobyl disaster based upon conventional risk methodology," In Chernobyl: 20 years 
on health effects of the Chernobyl accident, C.C. Busby, A.V. Yablokov, European Committee on Radiation Risk (ECRR), Aberystwyth, UK: Green Audit, 2006, pp. $245-248$.

24. A. Petryna, Life exposed: biological citizens after Chernobyl. Princeton; Oxford, UK: Princeton University Press, 2013.

http://doi.org/10.2307/j.ctt7rtb3.6

25. W. Huda, "Radiation doses and risks in chest computed tomography examinations," Proc. Am. Thorac. Soc., vol. 4, pp. 316-320, Aug. 2007.

http://doi.org/10.1513/pats.200611-172HT

26. D.J. Brenner, R.K. Sachs, "Do low dose-rate bystander effects influence domestic radon risks?” Int. J. Rad. Biol., vol. 78, no. 7, pp. 593-604, Aug. 2002. http://doi.org/10.1513/pats.200611-172HT

27. G. Lawler, "Knowledge and awareness of radiation therapy in the general Irish population and a population of health professionals," Radiother. Oncol., vol. 92, S157, Aug. 2009 http://doi.org/10.1016/So167-8140(12)72998-5

28. A. Turner, "Be wary of granite that glows," Houston Chronicle, Jul. 25, 2008.
Retrieved from:

http://rhic22.physics.wayne.edu/SaxumSubluceo/Stori es/HoustonChronicle GraniteCountertopsMayCauseYo uHarm.pdf

29. A. Ubysz, M. Maj, M. Musiał, J. Ubysz, "Radonoccurrence and health risks in civil engineering" Proc. Eng., vol. 172, pp. 1184-1189, 2017.

http://doi.org/10.1016/j.proeng.2017.02.138

3o. S. Živković, "Psihologija grupa," Niš: Fakultet zaštite na radu, Srbija, 2012.

(S. Živković, "Group Psychology," Niš: Faculty of Occupational Safety, Serbia, 2012.)

31. T. Perko, "Radiation risk perception: a discrepancy between the experts and the general population," J. Environ. Radioact., vol. 133, pp. 86-91, Jul. 2014. http://doi.org/10.1016/j.jenvrad.2013.04.005

32. Y. Kim, "The radiation problem and its solution from a health communication perspective," J. Korean Med. Sci., vol. 31 (Suppl 1), pp. S88-S98, Jan. 2016. http://doi.org/10.3346/jkms.2016.31.S1.S88 